\title{
Genetic structure and historical demography of the shanny Lipophrys pholis in the Portuguese coast based on mitochondrial DNA analysis
}

\author{
Sara M. Francisco ${ }^{a, b, *}$, Maria Natividade Vieira ${ }^{b}$, Vítor C. Almada ${ }^{a}$ \\ ${ }^{\text {a }}$ UIE, Instituto Superior de Psicologia Aplicada, Rua Jardim do Tabaco 34, 1149-041 Lisbon, Portugal \\ ${ }^{\mathrm{b}}$ Departamento de Zoologia e Antropologia, Faculdade de Ciências, Universidade do Porto, Praça Gomes Teixeira, 4099-002 Porto, Portugal
}

Received 24 October 2005; revised 14 December 2005; accepted 16 December 2005

Available online 24 January 2006

\section{Introduction}

The shanny Lipophrys pholis (Linnaeus, 1758) (Pisces: Blenniidae) is a rocky intertidal resident fish whose distribution comprises a large coastal region in Northeastern Atlantic, limited by Norway, Mauritania, and the Azores Islands (Zander, 1986). L. pholis has demersal eggs guarded by the males (Almada et al., 1992) that hatch after 16 days with $5.0 \mathrm{~mm}$ total length at a temperature of $17^{\circ} \mathrm{C}$ (Faria et al., 2002). Hatching larvae are well developed, settling at 13-14 mm TL after a pelagic larval duration of ca. 29 days at a temperature of $15.5-17.5^{\circ} \mathrm{C}$. After settlement and metamorphosis, this benthic species is thought to forage within a home range at high water and return to a particular set of rock pools or crevices at low tide (Dodd et al., 2000), with its movements being restricted to a small area.

In the Portuguese coast the stretches of rocky intertidal are widely separated by tens of kilometers of sandy shores. After settlement, the movements of $L$. pholis between the different rocky stretches are virtually impossible, and connectivity among populations must be ensured by larvae.

Fish larvae have long been considered passive particles at the mercy of ocean currents, tides, and weather events (Montgomery et al., 2001). For reef fishes, ecological evidence has demonstrated that passive dispersal alone cannot explain larval distributions (e.g., Leis and Carson-Ewart, 1998). Several studies have focused on early life-history traits (e.g., Doherty et al., 1995) and larval behaviour (e.g., Marliave, 1986; Miller and Shanks, 2004; Neilson and Perry, 1990) and tried to correlate them to dispersal potential. It would be interesting to understand if a coast with the range $(\mathrm{ca} .700 \mathrm{~km})$ and fragmentation of the Portuguese one bears just one or several populations of $L$. pholis.

\footnotetext{
* Corresponding author. Fax: +351 218860954.

E-mail address: sara_francisco@ispa.pt (S.M. Francisco).
}

Using mtDNA data, Stefanni et al. (in press) showed that the populations of the shanny can be separated in two distinct groups: one including fish from the Western European shores (from Scotland to Portugal and Madeira) and another comprising fish from the Azores.

The present genetic structure of a species can only be fully interpreted if one considers the influence of historical events and the complex interactions of biology, geography, and climatic shifts (Hewitt, 2000). It is known that during glaciations, the Atlantic shores of Western Europe underwent drastic changes in sea surface temperature. Alveirinho-Dias et al. (1997) showed that at the last glacial maximum (LGM, ca. 18.000 years ago), the waters along the Portuguese coast were many degrees colder than today, and the polar front was located at the latitude of Lisbon $\left(38^{\circ} 42^{\prime} \mathrm{N}, 9^{\circ} 10^{\prime} \mathrm{W}\right)$, or even south of that point. Thus, in its present composition, the ictiofauna of this geographical area is very young and must have been established after the end of the last glaciation, in the last 10 thousand years or so.

In the present work, mitochondrial DNA control region sequences were used to study populations of $L$. pholis along the Portuguese west and south coasts, specifically focusing on the following questions: (1) What is the degree of genetic differentiation of $L$. pholis along the Portuguese coast?; (2) Is there evidence of population expansion during Pleistocene for this species?; and (3) If no genetic differentiation is found, can we distinguish the effects of a post-glacial expansion from present day connectivity?

\section{Materials and methods}

Eighty nine specimens of $L$. pholis were collected between July 2003 and March 2005 from three rocky platforms along the Portuguese coast (Fig. 1): Cabo Mundo $\left(41^{\circ} 11^{\prime} \mathrm{N}\right.$, $\left.8^{\circ} 42^{\prime} \mathrm{W}\right)(n=27)$, Estoril $\left(38^{\circ} 42^{\prime} \mathrm{N}, 9^{\circ} 22^{\prime} \mathrm{W}\right)(n=31)$, and 


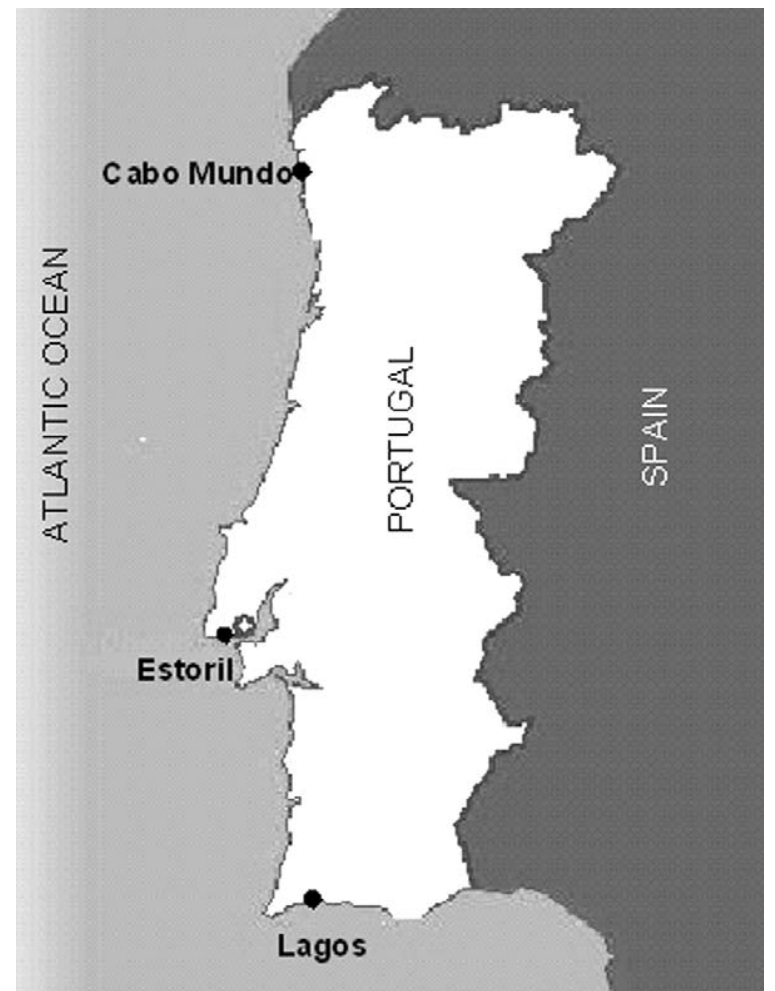

Fig. 1. Sampling locations for Lipophrys pholis along the Portuguese coast

Lagos $\left(37^{\circ} 05^{\prime} \mathrm{N}, 8^{\circ} 41^{\prime} \mathrm{W}\right)(n=31)$. A very small piece of dorsal fin was clipped and preserved in $96^{\circ} \mathrm{C}$ ethanol.

Total genomic DNA extraction was performed using the protocol of Sambrook et al. (1989) with some modifications. A fragment from the mtDNA control region was amplified using the primers described in Ostellari et al. (1996): L-pro1 and H-DL1. Details of DNA extraction, PCR, and sequencing may be requested from the authors. The obtained sequences were deposited in the GenBank Data Base (Accession Nos. DQ154169-4257; see Appendix in supplementary material).

Relationships among haplotypes were analyzed with a parsimony network estimated with TCS version 1.18 (Clement et al., 2000). The software PAuP* 4.0b (Swofford, 2000) was used to estimate the uncorrected $p$ distances between all sequences.

The ARLEQUIN software package version 2.000 (Schneider et al., 2000) was used to estimate the genetic diversity, to access population differentiation and to search for signs of past growth. The following diversity indices were computed: number of polymorphic sites, gene and nucleotide diversity (Nei, 1987), and average number of pairwise differences (Tajima, 1983). Analysis of molecular variance (AMOVA; Excoffier et al., 1992), pairwise $F_{\mathrm{ST}}$, and exact test for population differentiation (Raymond and Rousset, 1995) were performed. Mismatch analysis (Rogers, 1995; Rogers and Harpending, 1992) and Fu's $F_{\mathrm{s}}(\mathrm{Fu}, 1997)$ test were performed to test for a possible bottleneck and population expansion.
The program LAMARC (Kuhner et al., 2005), based on the coalescent theory of Kingman (1982a,b), was used to estimate the effective population size and $g$ (the exponential growth parameter in units of $\mu^{-1}$ ). Estimations of $\theta$ and $g$ were accomplished with 10 replicate runs using the default settings.

\section{Results}

The 89 sequences obtained define 67 haplotypes, 55 of which are represented in a single specimen. A total of 83 polymorphic sites and 93 mutations (80 transitions, 12 transversions, and 1 indel) were found out of a $380 \mathrm{bp}$ fragment of the mtDNA control region. All populations showed high values of gene and nucleotide diversity (Table 1).

The statistical parsimony procedure yielded one network (Fig. 2), with the exception of three haplotypes, which could not be connected together under the confidence limit of $95 \%$ (Templeton et al., 1992). This network revealed a lack of geographical structure. Within it there are several ambiguous connections, suggesting parallel substitutions, and haplotype 8 was inferred to be the ancestral one, as it yielded the highest outgroup weight (0.092) (Castelloe and Templeton, 1994). The uncorrected $p$ distances were $0.0300(\mathrm{SE}=0.0111), 0.0279 \quad(\mathrm{SE}=$ $0.0132)$, and $0.0269(\mathrm{SE}=0.0152)$ within Cabo Mundo, Estoril, and Lagos groups of samples, respectively, and $0.0311(\mathrm{SE}=0.0125)$ between Cabo Mundo and Lagos, $0.0312(\mathrm{SE}=0.0099)$ between Cabo Mundo and Estoril, and $0.0329(\mathrm{SE}=0.0137)$ between Estoril and Lagos. The average $p$ distance between the two more distant localities (Cabo Mundo and Lagos) is not greater than those between Cabo Mundo and Estoril and between Estoril and Lagos, suggesting that, at the scale of the present study, no effects of isolation by distance can be detected.

AMOVA of the D-loop sequence data revealed that the overall $F_{\mathrm{ST}}$ value was not significant (significance based on 1023 permutations), indicating no genetic structure within the studied area $\left(F_{\mathrm{ST}}=-0.0017, P=0.659\right)$. All pairwise $F_{\mathrm{ST}}$ values were smaller than 0.001 , and none of them were significant $(P>0.05)$. Similarly, exact tests of population differentiation indicated no significant difference $(P>0.05)$ for any pair of populations. Given these results, in the subsequent analyses the samples were pooled together, and treated as one single population.

Table 1

Diversity measures for the populations of Lipophrys pholis

\begin{tabular}{llllll}
\hline Population & $n$ & $n h$ & $S$ & $H$ & $\pi$ \\
\hline Cabo Mundo & 27 & 24 & 51 & 0.991 & 0.033 \\
Estoril & 31 & 27 & 58 & 0.991 & 0.031 \\
Lagos & 31 & 26 & 52 & 0.990 & 0.032 \\
Total & 89 & 67 & 83 & 0.990 & 0.032 \\
\hline
\end{tabular}

$n$, number of individuals; $n h$, number of haplotypes; $S$, number of polymorphic sites; $H$, gene diversity; and $\pi$, nucleotide diversity. 


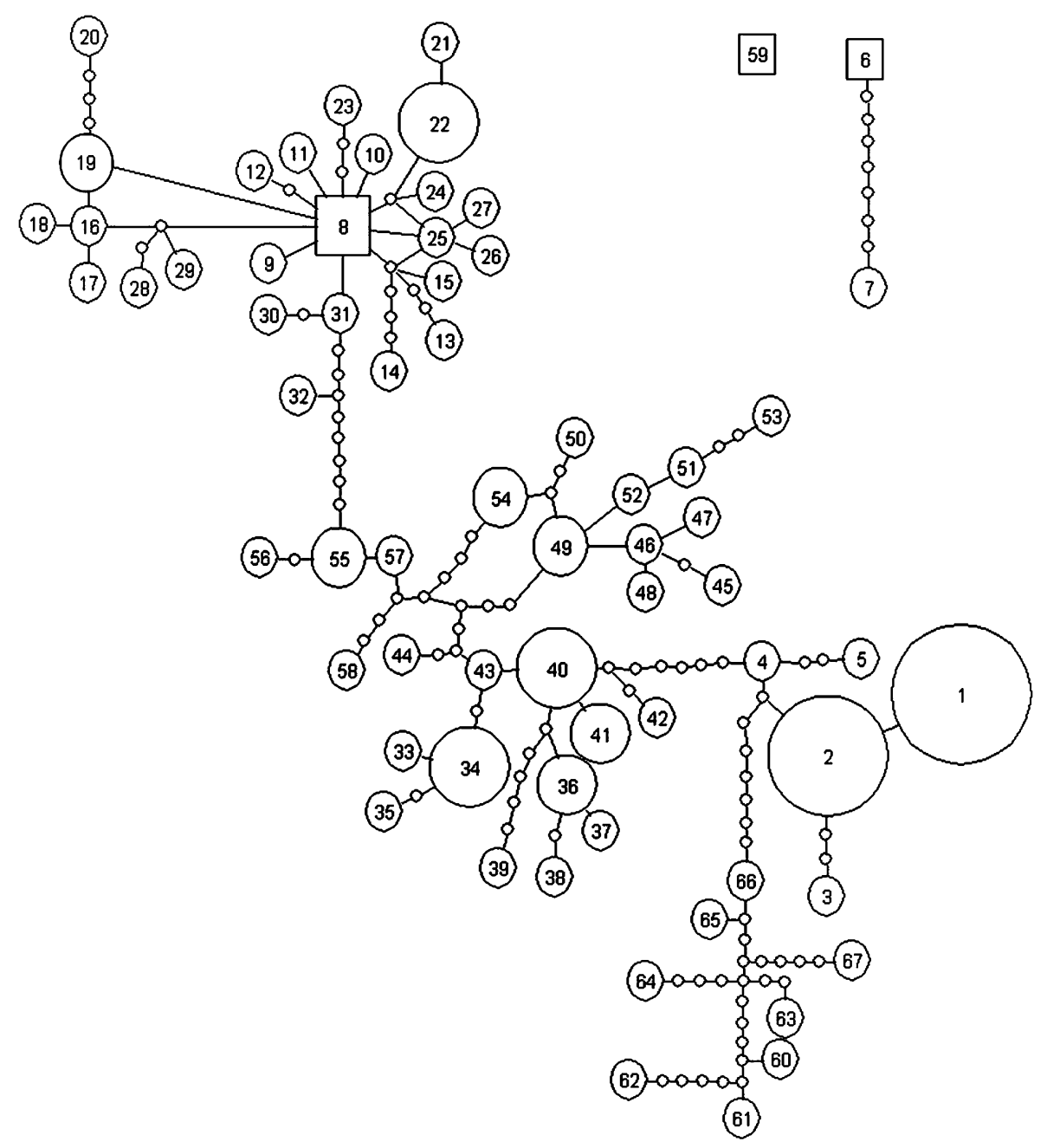

Fig. 2. Statistical parsimony network for the 67 D-loop mtDNA haplotypes of Lipophrys pholis in the Portuguese coast. Each haplotype is defined by its corresponding number (see Appendix). The haplotype with the highest outgroup probability is displayed as a square, other haplotypes as circles. The size of the squares or circles is proportional to the haplotype frequency.

The pairwise mismatch distributions were not significantly different from the sudden expansion model for the whole area (Table 2), outcome supported by Fu's test. There are very large discrepancies in estimations of divergence rates for the D-loop of teleosts. In the absence of a specific calibration for the D-loop of blennids we assumed two very distinct rates: 3.6 and $18.6 \%$ divergence per site per million years (Domingues et al., 2005; Donaldson and Wilson, 1999, respectively). For the whole Portuguese coast, expansion was estimated to have taken place approximately between 103,000 (95\% C.I. 72,566-125,771) and 531,000 years ago $(95 \%$ C.I. $374,927-649,817)$, depending on the mutation rate assumed and considering that $L$. pholis attains full maturity in 2 years (Milton, 1983).

Assuming a constant population size for L. pholis through time, the average $\theta$ value estimated with LAMARC was 0.1901 $(\mathrm{SE}=0.0118)$. Allowing the program to estimate both parameters jointly produced larger estimates of $\theta(0.4588$; $\mathrm{SE}=0.0612$ ), and the respective average growth rate was 197.2296 ( $\mathrm{SE}=18.4142)$. According to this model, the size of the female population $18 \mathrm{Kya}$ in the LGM was approximately $71.88-93.80 \%$ relative to its current size. The approximate age of shanny population, assessed as the age at which $N_{\mathrm{f}}$ drops below $1 \%$, yielded a value of $251,000-1,297,000$ years.

Table 2

Parameters of the mismatch distribution, Fu's neutrality test, and their significance for the whole population of Lipophrys pholis

\begin{tabular}{lllllllll}
\hline Population & $\tau$ & $\theta_{0}$ & $\theta_{1}$ & $S S D$ & $P$ & $H r i$ & $P$ & $F_{\mathrm{s}}$ \\
\hline Portuguese coast & $14.525(10.258-17.779)$ & 0.002 & 65.596 & 0.006 & 0.150 & 0.005 & 0.420 & -24.344 \\
\hline
\end{tabular}

$\tau$, time in generations, upper and lower bounds of $95 \% \mathrm{CI}$ in parenthesis; $\theta_{0}$ and $\theta_{1}$, compound parameter representing the mutation rate and the female effective population size before and after expansion, respectively; SSD, sum of square deviations and its probability $P$; Hri, Harpending's Raggedness index and its probability $P ; F$ s, Fu's neutrality test and its probability $P$. 


\section{Discussion}

The data indicated no significant population genetic structure in L. pholis along the Portuguese coast, which may be explained by three not mutually exclusive hypotheses. It may reflect ongoing gene flow. It can result from historical contacts between present-day populations. Finally, it may be the consequence of a colonization event so recent that there was not enough time for mutations to accumulate and population differentiation to occur.

Since the adults of $L$. pholis inhabit restricted rocky intertidal areas, gene flow must be maintained through larval dispersal. Like in other coastal species with demersal eggs, immediately after hatching the newly hatched larvae move to the surface, swim actively and one day after the onset of exogenous feeding occurs (Faria et al., 2002), traits that can be an indication of high dispersal potential. According to Faria et al. (1996), the breeding season in Portugal occurs from October/November to May, and during this period the coast is characterized by a permanent southward surface circulation $\left(30 \mathrm{~cm} \mathrm{~s}^{-1}\right.$ maximum speed), and a countercurrent associated with southerly winds that are formed during autumn-winter $\left(43 \mathrm{~cm} \mathrm{~s}^{-1}\right.$ maximum speed) (Fiúza, 1983; Martins et al., 2002). Thus, the net flow of the surface waters along the shore has a variable direction during winter and spring, depending on the relative proportion of winds that blow from the south which varies greatly along the winter and from year to year. The oceanographic conditions of the studied area may allow shanny larvae to migrate in both directions along the coast, and within the 30 days of pelagic larval duration they can potentially be transported up to $110 \mathrm{~km}$. These distances can be dramatically increased when storm conditions prevail, reaching about $200 \mathrm{~km}$ in 6 days (V.C. Almada, unpublished results). These findings are in apparent contradiction with the observations of Marliave (1986), who reported rocky intertidal fish larvae as being capable of resisting offshore, and possibly longshore, dispersal. Nevertheless, it is important to remember that larval dispersal may vary markedly with species, it may differ between sheltered and exposed sites, and, most importantly, even if substantial larval retention occurs, it is sufficient that a fraction of the larvae is transported away from the place of origin to ensure connectivity among populations. Accordingly, present day current regime and biological and behavioural characteristics of the larvae, potentially allow the exchange of individuals in sufficient numbers to prevent population divergence in $L$. pholis.

The results suggest that this species has undergone a population expansion in the Portuguese coast that lasted for several hundred thousands of years. According to the mismatch analysis this expansion may have began after a bottleneck that occurred between 73 and $650 \mathrm{Kya}$. It is also supported by significantly negative Fu's $F_{\mathrm{s}}$ and large difference between $\theta_{0}$ and $\theta_{1}$. Additionally, the approximate age of the population is $251,000-1,300,000$ years, clearly long before the LGM.
No signature of the LGM or other similarly recent bottleneck was detected in the mismatch distribution. In addition, the relative female effective population size $18 \mathrm{Kya}$ was only slightly smaller than today's (72-94\%).

In the LGM, and probably in other glacial maxima, polar water masses were at the Golf of Biscay, while at the western coast of the Iberian Peninsula the gradient of surface water temperature was extremely steep (from $0.7^{\circ} \mathrm{C}$ in the extreme NW to $7.2^{\circ} \mathrm{C}$ in the SW in February $18 \mathrm{Kya}$ ) (Climap, 1981). At the south coast of Portugal the surface water temperature was even higher $\left(9.0-10.3^{\circ} \mathrm{C}\right)$, equalling several points of the high latitudinal European coastal area in the present time. In such scenario, during glacial maxima, L. pholis populations may have persisted along the Iberian Peninsula, just by withdrawing a few hundred kilometers to the south.

All the lines of evidence presented above support the conclusion that the genetic homogeneity of shanny found along the Portuguese coast results from larval dispersal, and was not caused by a colonization event too recent to allow accumulation of mutations and population differentiation.

Stefanni et al. (in press) showed a large homogeneity in Dloop sequences of $L$. pholis populations from Great Britain to Madeira. One of the haplotypes described in Stefanni et al. (one individual from Oban, Scotland AY966030) is also shared by two of our individuals from Estoril-haplotype 8 (the one considered to be ancestral in the parsimony network). This finding suggests that the pattern of high connectivity found in the present work, may occur at a much wider geographical scale along the western European shores.

\section{Acknowledgments}

This research was supported by a grant from FCT to S.M. Francisco (SFRH/BD/12653/2003). The UIE-ISPA is funded by FCT through the pluri-annual and programmatic funding scheme (FEDER) as research unit UI\&D \#331/94. We thank N. Monteiro for his help with the field work at Cabo Mundo, and S. Stefanni et al. for allowing us to use their in press data for comparison purposes.

\section{Appendix A. Supplementary data}

Supplementary data associated with this article can be found, in the online version, at doi:10.1016/ j.ympev.2005.12.009.

\section{References}

Almada, V.C., Gonçalves, E.J., Oliveira, R.F., Barata, E., 1992. Some features of the territories in the breeding males of the intertidal blenny Lipophrys pholis. J. Mar. Biol. Assoc. UK 72, 187-197.

Alveirinho-Dias, J., Rodrigues, A., Magalhães, F., 1997. Evolução da linha de costa, em Portugal, desde o último máximo glaciário até à actualidade: Síntese dos conhecimentos. Estudos do Quaternário 1, 53-66.

Castelloe, J.T., Templeton, A.R., 1994. Root probabilities for intra-specific gene trees under neutral coalescent theory. Mol. Phylogenet. Evol. 3, 102-113. 
Clement, M., Posada, D., Crandall, K.A., 2000. TCS: a computer program to estimate gene genealogies. Mol. Ecol. 9, 1657-1659.

Climap Project Members, 1981. Seasonal reconstructions for the Earth's Surface at the Last Glacial Maximum, GSA Map \& Chart Serv., MC36, Geological Society of America, Boulder, Colorado.

Dodd, J., Gibson, R.N., Hughes, R.N., 2000. Use of cues by Lipophrys pholis L. (Teleostei, Blenniidae) in learning the position of a refuge. Behav. Process. 49, 69-75.

Doherty, P.J., Planes, S., Mather, P., 1995. Gene flow and larval duration in seven species of fish from the Great Barrier Reef. Ecology 76, 2373-2391.

Domingues, V.S., Bucciarelli, G., Almada, V.C., Bernardi, G., 2005. Historical colonization and demography of the Mediterranean damselfish, Chromis chromis. Mol. Ecol., 13. doi:10.1111/j.1365-294X.2005.02723.

Donaldson, K.A., Wilson, R.R., 1999. Amphi-Panamaic geminates of snook (Percoidei: Centropomidae) provide a calibration of the divergence rates in the mitochondrial DNA control region of fishes. Mol. Phylogenet. Evol. 13, 208-213.

Excoffier, L., Smouse, P.E., Quattro, J.M., 1992. Analysis of molecular variance inferred from metric distances among DNA haplotypes: application to human mitochondrial DNA restriction data. Genetics 131, 479-491.

Faria, C., Almada, V.C., Gonçalves, E.J., 1996. Juvenile recruitment, growth and maturation of Lipophrys pholis (Pisces: Blenniidae), from the west coast of Portugal. J. Fish Biol. 49, 727-730.

Faria, C., Borges, R., Gil, F., Almada, V.C., Gonçalves, E.J., 2002. Embryonic and larval development of Lipophrys pholis (Pisces: Blenniidae). Sci. Mar. 66, 21-26.

Fiúza, A.F.G., 1983. Upwelling patterns off Portugal. In: Suess, E., Thiede, J. (Eds.), Coastal Upwelling: Its Sediment Record. Plenum Publishing Corporation, pp. 85-98.

Fu, Y.X., 1997. Statistical tests of neutrality of mutations against population growth, hitchhiking and background selection. Genetics 147, 915-925.

Hewitt, G., 2000. The genetic legacy of the Quaternary ice ages. Nature 405, 907-913.

Kingman, J.F.C., 1982a. On the genealogy of large populations. In: Gani, J., Hannan, E.J. (Eds.), Essays in Statistical Science. Applied Probability Trust, London, pp. 27-43.

Kingman, J.F.C., 1982b. The coalescent. Stoch. Proc. Appl. 13, 235-248.

Kuhner, M.K., Yamato, J., Beerli, P., Smith, L.P., Rynes, E., Walkup, E., Li, C., Sloan, J., Colacurcio, P., Felsenstein, J., 2005. LAMARC Version 2.0. University of Washington, http://evolution.gs.washington.edu/ lamarc.html.

Leis, J.M., Carson-Ewart, B.M., 1998. Complex behaviour by coral-reef fish larvae in open-water and near-reef pelagic environments. Environ. Biol. Fishes 53, 259-266.

Marliave, J.B., 1986. Lack of planktonic dispersal of rocky intertidal fish larvae. Trans. Am. Fish. Soc. 115, 149-154.
Martins, C.S., Hamann, M., Fiúza, A.F.G., 2002. Surface circulation in the eastern North Atlantic from drifters and altimetry. J. Geophys. Res. $107,3217$.

Miller, J.A., Shanks, A.L., 2004. Evidence for limited larval dispersal in black rockfish (Sebastes melanops): implications for population structure and marine-reserve design. Can. J. Fish. Aquat. Sci. 61, 1723-1735.

Milton, P., 1983. Biology of littoral blenniid fishes on the coast of SouthWest England. Symp. Zool. Soc. Lond. 44, 263-306.

Montgomery, J.C., Tolimieri, N., Haine, O.S., 2001. Active habitat selection by pre-settlement reef fishes. Fish 2, 261-277.

Nei, M., 1987. Molecular evolutionary genetics. Columbia University Press, New York.

Neilson, J.D., Perry, R.I., 1990. Diel vertical migrations of juvenile fish: an obligate or facultative process? Adv. Mar. Biol. 106, 115-168.

Ostellari, L., Bargelloni, L., Penzo, E., Patarnello, P., Patarnello, T., 1996. Optimization of single-strand conformation polymorphism and sequence analysis of the mitochondrial control region in Pagellus bogaraveo (Sparidae, Teleostei): rationalized tools in fish population biology. Anim. Genet. 27, 423-427.

Raymond, M., Rousset, F., 1995. An exact test for population differentiation. Evolution 49, 1280-1283.

Rogers, A.R., 1995. Genetic evidence for a Pleistocene population explosion. Evolution 49, 608-615.

Rogers, A.R., Harpending, H., 1992. Population growth makes waves in the distribution of pairwise genetic differences. Mol. Biol. Evol. 9, 552 569.

Sambrook, J., Fritscher, E.F., Maniatis, T., 1989. Molecular Cloning: A Laboratory Manual, second ed. Cold Spring Harbour Laboratory Press, New York.

Schneider, S., Roessli, D., Excoffier, L., 2000. ARLEQUIN Version 2.000: A Software for Population Genetics Analysis. University of Geneva, Geneva.

Stefanni, S., Domingues, V., Bouton, N., Santos, R.S., Almada, F., Almada, V., in press. Phylogeny of the shanny, Lipophrys pholis, from the NE Atlantic using mitochondrial DNA markers. Mol. Phylogenet. Evol., doc:10.1016/j.ympev.2005.07.001.

Swofford, D.L., 2000. PAUP* Phylogenetic Analysis Using Parsimony (* and other methods), Version 4. Sinauer Associates Inc., Sunderland, MA, USA.

Tajima, F., 1983. Evolutionary relationship of DNA sequences in finite populations. Genetics 105, 437-460.

Templeton, A.R., Crandall, K.A., Sing, C.F., 1992. A cladistic analysis of phenotypic associations with haplotypes inferred from restriction endonuclease mapping and DNA sequence data. III. Cladogram estimation. Genetics 132, 619-633.

Zander, C., 1986. Blenniidae. In: Whitehead, P., Bauchot, M.L., Hureau, J.C., Nielsen, J., Tortonese, E. (Eds.), Fishes of the North-eastern Atlantic and the Mediterranean. UNESCO, Paris, pp. 1096-1112. 